\title{
DEVELOPING INDUSTRIAL WATER REUSE SYNERGIES IN PORT MELBOURNE: COST-EFFECTIVENESS, BARRIERS AND OPPORTUNITIES
}

\author{
Damien GIURCO ${ }^{1, *}$, Albena BOSSILKOV ${ }^{2}$, James PATTERSON $^{1}$, Alex KAZAGLIS $^{1}$ \\ ${ }^{1}$ Institute for Sustainable Futures, University of Technology Sydney (Australia) \\ ${ }^{2}$ Centre for Excellence in Cleaner Production, Curtin University of Technology (Australia) \\ *Corresponding author, tel: +61 29514 4978, fax: +61 29514 4941, \\ email: Damien.Giurco@uts.edu.au
}

\begin{abstract}
Urban water scarcity from ongoing drought and an increasing population are driving a range of water saving options to be explored in Melbourne (Australia). This paper assesses the cost-effectiveness of five water treatment and industrial reuse options in the Fishermans Bend industrial area at Port Melbourne. In consultation with industrial stakeholders and the local water utility, the study design began by identifying potential water sources and sinks in the area. Treatment technologies for each option - using a combination of membrane bioreactors (MBR) and in some cases reverse osmosis $(\mathrm{RO})$ technologies - were developed. In evaluating the potential for future implementation, the cost effectiveness (\$/kiloLitre) was assessed relative to water supply augmentation and water demand management options available in Melbourne. Additionally, the opportunities and barriers for option implementation in Port Melbourne were contrasted with the Kwinana Industrial Area, Western Australia where many regional synergy projects have been undertaken. This identifies that the future implementation of industrial ecology opportunities requires strong and ongoing stakeholder involvement as described in this paper.
\end{abstract}

Keywords: water; recycling, industrial ecology; regional synergies

\section{INTRODUCTION}

\subsection{Industrial symbiosis and regional synergies}

Industrial Symbiosis is perhaps the best-known application of industrial ecology principles. It deals with the exchange of by-products, water, energy, and process wastes among closely situated firms [1-6]. Because of the many links between firms, 
an industrial area is transformed into an 'industrial ecosystem'. Synergistic links between firms are labelled 'industrial symbiosis' as defined by Chertow: "Industrial symbiosis engages traditionally separate industries in a collective approach to competitive advantage involving physical exchange of materials, energy, water, and/or by-products. The keys to industrial symbiosis are collaboration and the synergistic possibilities offered by geographic proximity" [7]. Localised industrial ecology in the form of industrial symbiosis could also have the broader benefit of linking to regional development [8]. The related term 'regional synergies' was formulated in 2005 as a result of a study focused to encourage and facilitate the greater utilisation of regional synergy opportunities to improve the overall ecoefficiency of resource processing intensive regions [9]. The study found several other terms and definitions for Industrial Symbiosis, with a common implementation aim at 'creating a system for trading material, energy, and water by-products among companies, usually within a park, neighbourhood, or region' [10]. In the present paper, the authors use the term 'regional synergies', as it better emphasises the broader cooperative organisational focus of the activity based on the synergistic use of water, energy or by-products (rather than giving primary focus to the synergistic use of materials and energy via collaboration).

Both industrial symbiosis and regional synergies have a focus on the benefits of promoting inter-firm exchanges, for waste, energy and water, however less attention has been given to how the waste hierarchy often phrased as 'reduce, reuse, recycle' [11] applies differently with waste, energy and water. For waste, one can minimise resource use on-site and then with whatever is left as a solid waste product, seek to find a use at a neighbouring firm for the product. Similarly for energy, recovery and use of low grade heat from one processes for another is common. By contrast, with water there is a greater tension between reducing on-site use though water use efficiency (which is generally cheaper and conserves the water resource in the first place), if there is a water recycling or reuse synergy, which created a symbiotic relationship with a neighbouring firm. In addition to providing safe and reliable water supplies, Australia's National Water Initiative seeks to increase water use efficiency and as Lowe [12] notes, "The trading of wastes as byproducts is not a good in itself if there are more effective waste reduction solutions upstream." The tension can manifests where using less water on site leads to an increasing concentration in wastewater discharges, which in turn requires greater treatment costs (and resources). In integrated resources planning for urban water [13-17] a cost effectiveness framework is used to rank the desirability of efficiency versus recycling 
options for conserving water in the city and the options proposed in this paper will be discussed in this context, together with barriers and opportunities for regional synergy development. This contrasts the industrial symbiosis and industrial ecology literature where, even with a water focus (such as [18] or [19] who even mentions integrated resources planning) there is little discussion of how to reconcile trade offs between options promoting recycling versus options promoting efficiency.

\subsection{Sustainable urban water management in Australia}

Whilst approximately $70 \%$ of water in Australia is used in agriculture and irrigation, $15 \%$ in industry and $15 \%$ in residential demand, in urban centres where water is generally sourced from localised catchment unconnected from major river systems, the majority of water is used by residential customers (householders), rather than industry. In the Melbourne area, annual water consumption is approximately $470 \mathrm{GL}$ divided between the following uses: $60 \%$ in residential homes, $30 \%$ in industry and commercial uses, $10 \%$ in non-revenue water [20]. Consequently, water saving initiatives are directed toward both residential consumers and industry, and the relative costs for saving water in each sector become highly relevant to which options the government-owned utility pursues (which serves both residential and commercial/industrial sectors). Urban water scarcity from drought, climate change and an increasing population are driving a range of water saving options to be explored and implemented in Melbourne and indeed throughout Australian cities [17, 20, 21]. Options developed by government-owned water utilities in Australian cities to reduce water use include: encouraging the uptake and installation of water efficient toilets, low flow showerheads and water efficient washing machines; the installation rain tanks in homes and industry; assisting industry to save water through efficiency and recycling initiatives; and the construction of a desalination plants in addition to the existing rain-fed water supply system.

One strategy to reduce the industrial demand on the centralised supply system would be to recycle water between companies within a heavy industrial area such as Port Melbourne. This initial activity could also encourage companies to pursue further initiatives to reduce impacts related to energy and waste. A scoping study of the technologies, costs, barriers and opportunities for water reuse synergies forms the focus of this paper. Water reuse synergies have been identified and successfully implemented at other industrial areas in Australia, most notably in Kwinana, Western Australia [22] and similarities and differences between the barriers and drivers are 
discussed in this paper. The Kwinana Industrial Area in Western Australia is used a comparison example in this paper as is was found to be one of the best international examples of regional synergy development, in terms of the level and maturity of the industry involvement and collaboration, and the commitment to future regional resource synergy projects [9].

\subsection{Aims}

The aims of this paper are to:

1. Explore potential industrial water reuse synergies identified in the Port Melbourne area and the process by which they were developed;

2. Evaluate the role of a cost-effectiveness framework in prioritising reuse synergy options relative to other water saving options in the urban context;

3. Discuss the barriers and drivers for implementation of industrial water reuse synergies in Port Melbourne, and contrast them with the barriers and drivers in Kwinana, Western Australia;

4. Recommend generalised areas for further research - informed by the industrial symbiosis literature - to overcome barriers and promote the appropriate development of regional synergies.

\section{APPROACH}

\subsection{Background to Port Melbourne case study}

This project was initiated by the Victorian Smart Water Fund ${ }^{1}$ to explore the potential for industrial ecology opportunities in Melbourne. Following a literature and data review and consultation with industries in different parts of Melbourne, the Port Melbourne case study site was selected. A key factor the selection of this site, was that the companies had a commitment for exploring inter-company synergies and had already begun doing so of their own accord, thus the project could build on established buy-in from participants. The site is based in the Fishermans Bend area of Port Melbourne, an industrial zone located less than three kilometres from the centre of Melbourne, with historically much heavy industry and more recently increasing commercial and light industrial developments alongside established manufacturing and production sites. It is also located adjacent to residential and commercial urban renewal project at Docklands.

\footnotetext{
${ }^{1}$ The Smart Water Fund was established by the Victorian Government and (governmentowned) water retailers in Melbourne to encourage and support innovative development of water and biosolids recycling and water saving projects within the community. See www.smartwater.com.au
} 
The companies located at the Fisherman's Bend site in Port Melbourne that participated in this study, along with the industrial activities performed by each company are:

- Kraft (food production)

- Boral (plasterboard production)

- General Motors Holden (automotive manufacturing)

- Boeing (metal component manufacture, soon to be carbon fibre manufacture)

- Symex (commercial fats and proteins production)

- Herald and Weekly Times (HWT) (newspaper printing)

- Crema Group (precast concrete manufacture)

- Independent Cement (cement production and precast manufacture).

\subsection{Overview of approach}

Preliminary stages of the broader project included a literature review of approaches to regional synergies identification [23], presentation to stakeholders from government and industry to identify potential case study sites, and development of a systematic approach for prioritising potential case study sites across Melbourne. This approach sought to combine generic industry locations based on information from the Australian Bureau of Statistics with generic input-output characteristics for industry types based on inventory databases in LCA software to identify potential sources and sinks for water and other materials and regional synergy 'hot spots' in Melbourne. The approach did not work as the generic data available on industry types in different areas of the city was too aggregated to identify specific areas of opportunity and average input output data from LCA software was not representative enough of local conditions. The application of a regional synergy toolkit developed and used in Kwinana was also considered, however was deemed to be too data intensive for this project which was focussed primarily on water synergies [24].

Rather, the selection of the Port Melbourne case study was made in consultation with the water utility that had been approached by companies in the area seeking to explore water reuse opportunities. Ultimately, this was most favourable as opportunities initiated by industry themselves have been found to be more successful than those initiated by governments or regional authorities [25]. 
The details of the approach taken in this case study are shown in Figure 1. The scope of the investigation was to identify water recycling opportunities between companies, rather than within companies or other on-site efficiency options (as these investigations are occurring through other programs lead by the water utility).

Figure 1: Overview of approach

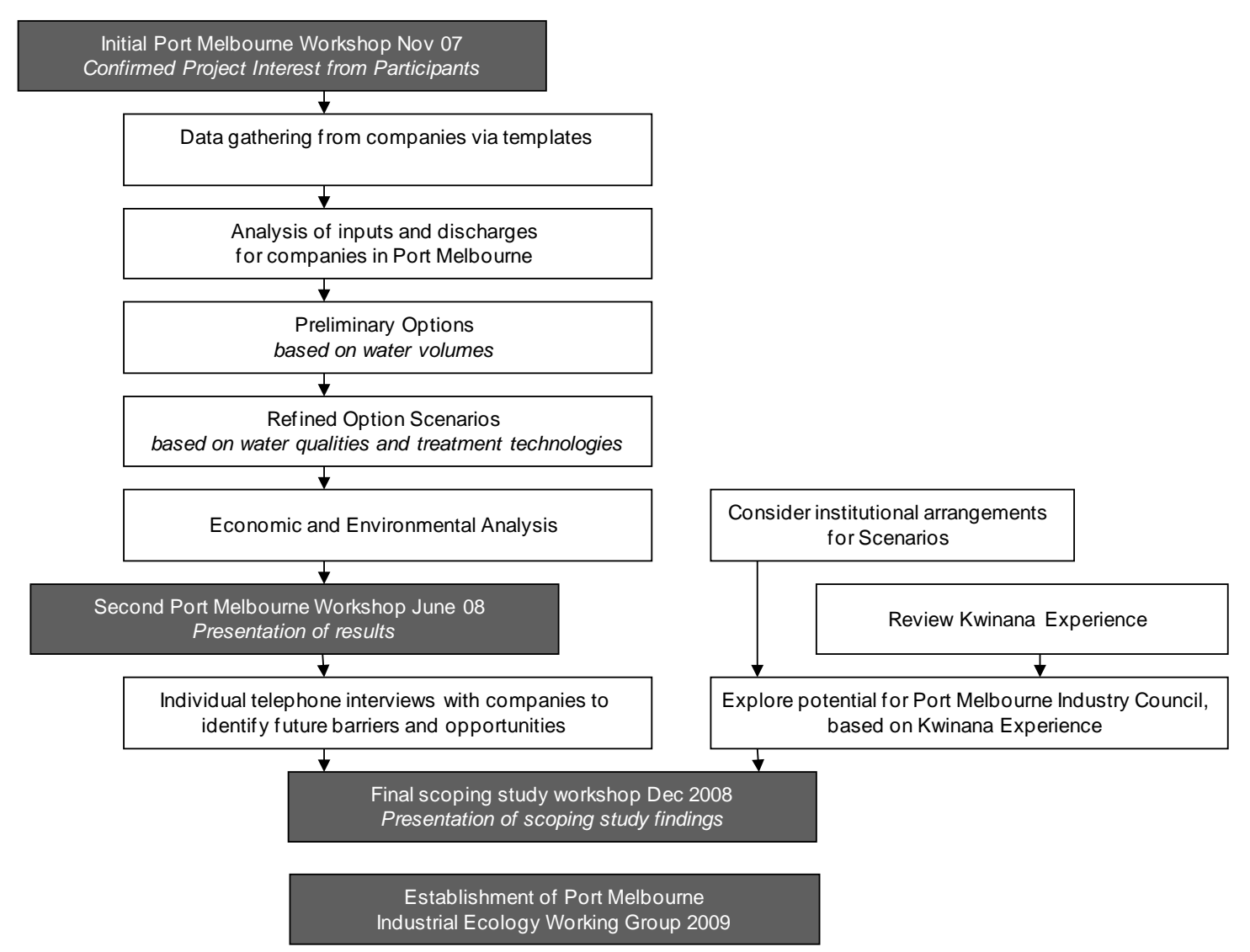

\subsubsection{Data Collection and option development}

Data on the water inflows, outflows and quality of discharges and required inputs was gathered from each of the participating companies using a template, requesting quantitative and qualitative data for input and output water streams.

The collected enabled a graphical mapping of potential water sources and sinks across the study area, based initially only on volumes. Inputs ranged from $5 \mathrm{~kL} /$ day to $700 \mathrm{~kL} /$ day and discharges ranged from $2 \mathrm{~kL} /$ day to $400 \mathrm{~kL} /$ day. Two broad classes of generalised options were then explored, the first having a centralised treatment facility involving all major companies and the second involving pairs of individual companies, one acting as the source and the other as a sink. 
Detailed options were developed using the water quality data (initially to match discharge and required input $\mathrm{pH}$ ) in addition to quantity data, including required technologies and costs. The latter are discussed further in Section 3. The economics of each option, including capital and operating costs together with cost effectiveness analysis (\$/kilolitre) was then calculated.

\subsubsection{Cost effectiveness Framework for Option Assessment}

Water reuse synergies identified in this paper were evaluated using a costeffectiveness framework ( $\$ /$ kilolitre) based on levelised unit cost as described by White and Fane [14, 28]. Cost-effectiveness is the cornerstone of Integrated Resources Planning which has been advocated in the water and energy industries for comparing supply augmentation and demand reduction measures on an equal footing $[21,26]$. Its use in this case study is twofold. Firstly, it is to rank the costeffectiveness of the reuse synergy options developed on an equivalent basis. Secondly, it is used to compare the water reuse synergy options relative to other options such as on-site water demand reduction (efficiency) measures (e.g. from the installation of more water-efficient technologies such as showers, toilets and other equipment, or changed water-using behaviours such as using less water during cleaning) and also desalination which the utility could consider implementing in order to ensure supply-demand balance in the longer term. Energy impacts were considered in addition to financial costs.

\subsubsection{Implementation barriers and drivers}

The options for regional water synergies between companies were presented to participating companies at a second workshop. Feedback at the workshop on barriers and drivers was followed up with individual discussions with companies and the experiences were compared with those of Kwinana, Western Australia, where there has been experience in implementing regional water synergies [22]. An important aspect of the Kwinana model was the central role played by the Kwinana Industries Council. Consequently a similar industry-based reference group was proposed and has led to the formation of an industrial ecology working group amongst the Port Melbourne companies following the conclusion of the scoping study to assist with further development of options and implementation. 


\section{RESULTS AND DISCUSSION}

This section presents the options and technologies identified, their cost effectiveness as well as an introduction to barriers and opportunities associated with option implementation.

\subsection{Technology options}

Five water reuse options investigated are presented in Figure 2. 
Figure 2: Overview of options

Option 1: Recover 275kL/day of wastewater from Kraft using MBR to produce $250 \mathrm{~kL}$ of Class A quality water for reuse at Boral

Symex, HWT

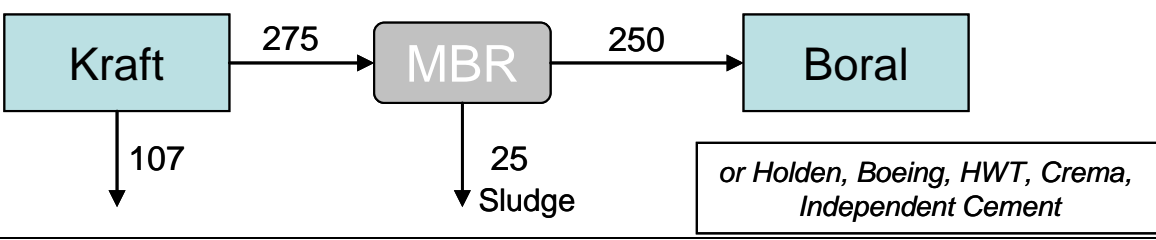

Option 2: Recover 382kL/day of wastewater from Kraft using MBR to produce around $282 \mathrm{~kL} /$ day of Class A water for reuse at Boral, Crema, Independent Cement

Symex, HWT

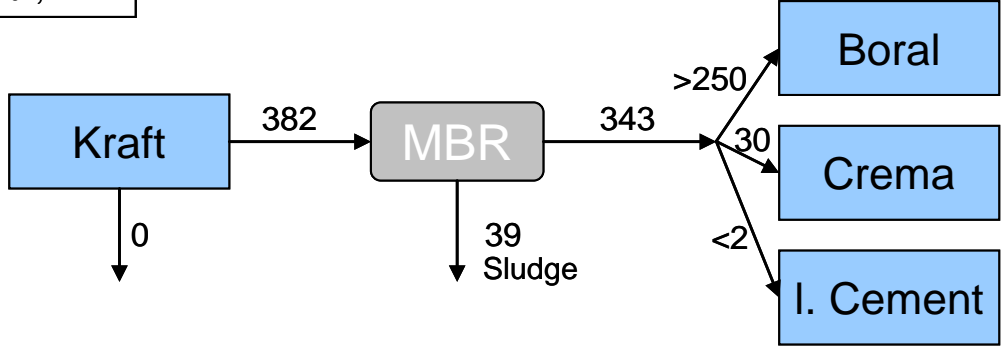

or Holden, Boeing, HWT

Option 3: Recover 310kL/day of wastewater from Kraft using MBR and R/O on 50\% of the MBR Class A product stream, to produce $250 \mathrm{~kL} /$ day of lower-salt water for reuse at Boral

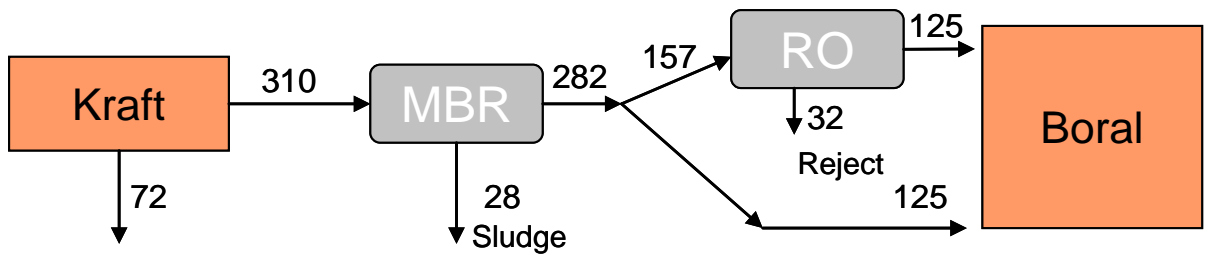

Option 4: Recover 343kL/day of wastewater from Kraft using MBR and R/O polishing of the entire Class A stream to produce $250 \mathrm{~kL} /$ day of very high quality water for reuse at Boral

Symex, HWT

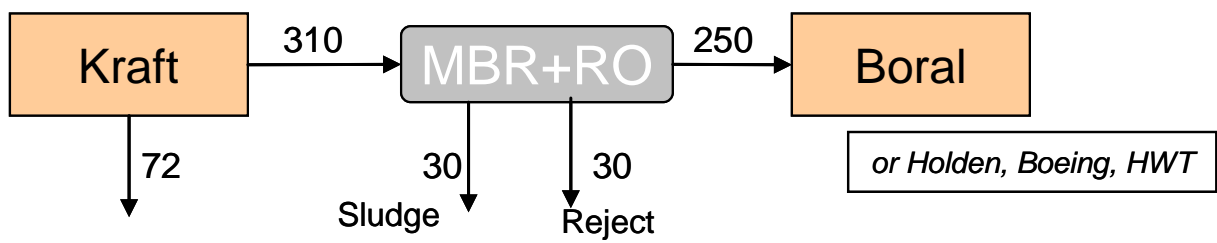

Option 5: Recover $175 \mathrm{~kL} /$ day of wastewater from Kraft using MBR and 50\% potable water dilution to generate $250 \mathrm{~kL} /$ day of low salt water for use at Boral

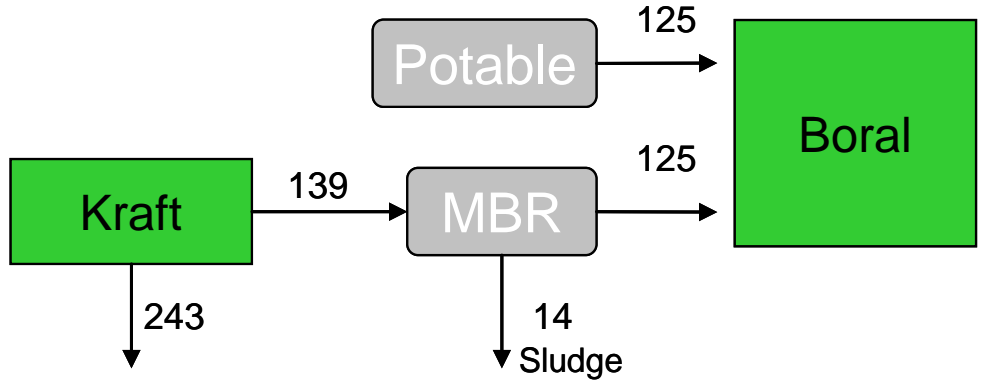


The major companies that were assumed to be sources of wastewater or sinks for reclaimed water are given in the coloured/shaded boxes in the figure for indicative purposes, and other possible companies that could function in these roles are also given in separate boxes in italics in the figure. The specific water volumes depicted are based on data collected directly from companies; $382 \mathrm{~kL} /$ day is the maximum available for recycling from Kraft (determining volumes in Option 2) and $250 \mathrm{~kL} /$ day is approximately the volume which Boral could accept as recycled water (determining volumes in Options 1, 3, 4, 5).

Two assumptions in calculating the quantities of water produced by each scenario were made:

- $\quad 9 \%$ loss in water volume due to sludge generation from the MBR treatment process;

- $20 \%$ loss in water volume within the retentate / reject stream from an RO process used to polish either part or all of the Class A water in some scenarios.

This treatment train abbreviated in Figure 2 as "MBR" consists of the following five upstream and downstream components with the Membrane bioreactor (MBR) technology being the central component:

1. Upstream anaerobic sludge blanket (UASB) pre-treatment stage,

2. Aerobic activated sludge process to reduce $B O D$,

3. Anoxic stage to reduce nutrient concentrations,

4. Membrane bioreactor itself (MBR) stage (incorporating ultrafiltration) to produce Class A reclaimed water, and

5. UV disinfection stage.

Reverse Osmosis (RO) technology to remove salt load is depicted additionally in options 3 and 4.

High BOD/COD, suspended solids (SS) and nutrient (nitrogen and phosphorous) loads in source wastewater from Kraft will require a biological treatment process to reduce these levels to comply with Class $A$ reclaimed water criteria ${ }^{2}$. As a consequence the treatment system included a combination of the three established

\footnotetext{
${ }^{2}$ Class A water may be utilised for urban (non-potable) use with uncontrolled public access; agricultural use e.g. human food crops consumed raw or industrial use in open systems with worker exposure potential [27] EPA Victoria. Use of reclaimed water. Guidelines for environmental management. Melbourne: Environmental Protection Authority Victoria; 2003.
} 
processing systems treatment process types, i.e. anaerobic followed by anoxic followed by aerobic.

The upflow anaerobic sludge blanket (UASB) technology can treat high organic loads and is followed with a complete mix activated sludge plant which is less susceptible to shock loads while maintaining effective BOD and phosphorous removal. The levels of nitrogen in the waste water require an anoxic denitrification step. The anoxic step would be operated with sequential mixing and settling and will be operated in conjunction with membrane bioreactor modules (MBR) to allow the retention of higher biomass concentration, negate the need for a substantial sized clarifier, reduce the risk associated with SS carryover into the reclaimed water, and minimize the requirements for disinfection. The MBR unit contains ultrafiltration membranes which effectively eliminates SS and reduces bacteria populations to below the Class A limits. The final UV disinfection stage minimises the risk of pathogens that may have passed through the membrane.

Installing a balance tank allows for flow balancing by reducing peak flow to the system and storing a portion of the daily peak to equalise the characteristics of the product water. Furthermore, this will allow a volume to be delivered to the system during low flow periods, especially after-hours and weekends, to maintain the efficiency of the biological activity in the system.

Further issues associated with implementation of the treatment enabling the regional synergy for water include land availability, odour control and sludge disposal.

\subsection{Assumptions, capital and operating costs, cost-effectiveness, energy intensity}

An economic analysis was conducted to evaluate each of the options shown in Figure 2.

The financial viability of each scenario and the cost-effectiveness (\$/kiloLitre) of water supplied in each option was calculated and compared in Table 1. The intention of the analysis in Table 1 is not to identify one preferred option, but to investigate 
how the financial viability and cost-effectiveness ${ }^{3}$ differ between the scenarios, to assess the potential for regional synergy implementation.

The assumptions made in the economic analysis are given below:

Cost elements included:

- Treatment plant capital costs (including plant construction, equipment, and balance tanks);

- Operating costs (including energy costs, trade waste costs).

Cost elements excluded:

- Costs of land acquisition were excluded and could be significant;

- Pipeline costs were calculated to be AUD100-300 per metre and given the distances involved of up to $200 \mathrm{~m}$, this equates to AUD20-60,000 which is deemed not significant in a multi million dollar project.

Treatment plant construction and operation:

- The major structural elements of the plant are designed and constructed for a minimum of a 20 year life span (economic modelling done for 10 year time frame);

- Membranes on the MBR will require replacement at 3-5 years while RO membranes if installed may require replacement at 1-2 years;

- Other operating equipment such as pumps, blowers, diffuser membranes, valves will need regular maintenance and have life spans of around 5 years;

- Plant construction could be completed within a 12 month time frame;

- Plant operates for 300 days/year.

Water input charges and energy tariffs:

- Current water tariff taken as $\mathrm{A} \$ 1.00 / \mathrm{kL}$, and water and trade waste tariffs are planned to increase at $14.8 \%$ p.a. from 2009-2013 [29] and assumed 5\% p.a. increase into future beyond 2013;

- Water prices charged for reclaimed water are assumed to be $85 \%$ of potable water prices (author estimate) to provide an incentive for companies to purchase the recycled water;

\footnotetext{
${ }^{3}$ Cost effectiveness was calculated using the levelised cost of water [28] Fane SA, Robinson $\mathrm{J}$, White S. The use of levelised cost in comparing supply and demand side options for water supply and wastewater treatment. Water supply. 2003;3(3):185-92.
} 
- Energy tariff assumed to be 10 cents/kWh [30] and forecast as fixed into future, this is likely to be an underestimate as energy prices would be expected to rise.

Economic analysis:

- $7 \%$ discount rate (as used by water utility);

- Forecast horizon for plant operation was 10 years (beginning 2009);

- Straight line depreciation (10\% p.a.) of assets over forecast horizon.

Table 1: Capital and operating costs, cost effectiveness and energy intensity

\begin{tabular}{ccccc}
\hline Option & $\begin{array}{c}\text { Approx. capital } \\
\text { cost (AUD) }\end{array}$ & $\begin{array}{c}\text { Approx. operating } \\
\text { cost (AUD/yr) }\end{array}$ & $\begin{array}{c}\text { Cost effectiveness } \\
\text { (AUD/kL) }\end{array}$ & $\begin{array}{c}\text { Energy intensity } \\
\text { (kWh/kL) }\end{array}$ \\
\hline 1 & $\$ 2500000$ & $\$ 420000$ & $\$ 9 / \mathrm{kL}$ & 15.4 \\
\hline 2 & $\$ 2700000$ & $\$ 550000$ & $\$ 8 / \mathrm{kL}$ & 15.0 \\
\hline 3 & $\$ 2700000$ & $\$ 570000$ & $\$ 14 / \mathrm{kL}$ & 19.2 \\
\hline 4 & $\$ 2800000$ & $\$ 730000$ & $\$ 18 / \mathrm{kL}$ & 28.1 \\
\hline 5 & $\$ 2700000$ & $\$ 490000$ & $\$ 27 / \mathrm{kL}$ & 15.4 \\
\hline
\end{tabular}

Table 1 shows similar capital costs for all options, but increased operating costs for options 3 and 4 involving reverse osmosis. The cost effectiveness is also higher for options 3 and 4 involving reverse osmosis than for 1 and 2 which use MBR only. Option 5 has the highest cost per $\mathrm{kL}$ of water as it also includes the purchase of potable water for diluting the final salt content of the recycled water.

In comparison with a range of water demand and supply options, water recycling options can be (and in this case are) expensive, particularly due to the limited size of the recycling facility. Were the facility to be larger, greater economies of scale could be realised, thereby reducing the unit cost. For example, water demand reduction (efficiency) options can vary between $A \$ 0.05 / \mathrm{kL}$ to $A \$ 1.50 / \mathrm{kL}$, and desalination can vary between $A \$ 2 / k L$ to $A \$ 5 / k L[17,31]$. The usefulness of using a cost effectiveness frameworks is to raise the question of whether the utility would pay for this activity as a water saving measure when it can save or supply water more cheaply with other options. The options developed are not self sufficient from a cost perspective as outlined later and hence would not be implemented by companies in the absence of 
financial assistance. There are also regulatory barriers to the companies themselves acting as third party water suppliers/recyclers ${ }^{4}$.

The MBR options (options 1, 2 and 5) generate a unit energy demand of approximately $15 \mathrm{kWh} / \mathrm{kL}$ of wastewater treated, and option 4 which is $100 \% \mathrm{RO}$ approximately doubles this energy demand to $28 \mathrm{kWh} / \mathrm{kL}$. The current average energy intensity of water supply, distribution, pumping and treatment across Victoria is approximately $0.87 \mathrm{kWh} / \mathrm{kL}$, and therefore this water recycling option will be highly energy intensive relative to catchment-based supplies and also compared to unit energy intensities reported for recent desalination projects across Australia. This could result in an increased energy demand of up to 1,100-2,300 MWh/a for a 250 $\mathrm{kL} /$ day plant, or 1,500-3,000 MWh/a for a $340 \mathrm{~kL} /$ day plant. Depending on the greenhouse intensity of electricity used to power the treatment facility, this could produce greenhouse gas emissions of between $1,500-3,000$ t/a or a $250 \mathrm{~kL} /$ day plant, or 2,000-4,000 t/a for a $340 \mathrm{~kL} /$ day plant.

With the planned implementation of an Australian Carbon Pollution Reduction Scheme (CPRS) in 2013 it is likely that energy prices will increase due to a carbon cost component being passed onto consumers through increased energy tariffs and this could further reduce the financial viability of a water recycling scheme.

In order to mitigate the significant additional energy and greenhouse costs of this type of scheme, various energy options should be investigated and concurrently implemented. These could range from energy recycling among the group of companies at the site including utilisation of waste heat, utility sharing of cogeneration capacity and boilers which are currently underutilised at various companies, installation of solar power to supply or augment energy for the treatment plant, or purchase of lower carbon-intensity electricity to supply the energy for the scheme. Overall, it will be essential to consider the energy implications of future options in addition to potable water savings.

Cumulative cash flow after ten years is given in Table 2. None of the options are cash flow positive after ten years time unless some form of financial support is

\footnotetext{
${ }^{4}$ Whilst third party operators can be water utilities in other parts of Australia, in particular, New South Wales (NSW) [32] Independent Pricing and Regulatory Tribunal (New South Wales). WICA Fact Sheet: Overview of licensing regime under the Water Industry Competition Act 2006. 2008., this is not possible in Melbourne, Victoria.
} 
offered to the companies for implementation. The form of support outlined in the table is '0\% interest on loan' and an AUD 2,000,000 capital grant.

Table 2:Cumulative cash flow after 10 years (negative figures bracketed)

\begin{tabular}{lcc}
\hline \multicolumn{1}{c}{ Option } & \multicolumn{2}{c}{$\begin{array}{c}\text { Cumulative Cash Flow after } \\
\text { 10 years (\$million, Australian Dollars) }\end{array}$} \\
\cline { 2 - 3 } & $\begin{array}{c}\text { All capital costs } \\
\text { loaned at 0\% } \\
\text { interest }\end{array}$ & $\begin{array}{c}\text { \$2m capital grant \& } \\
\text { 10\% interest on } \\
\text { remaining loaned } \\
\text { funds }\end{array}$ \\
\hline $\begin{array}{l}\text { 1: } 250 \mathrm{~kL} / \text { day output MBR, one-to-one (Kraft-to- } \\
\text { Boral) or many-to-many }\end{array}$ & $\$ 450000$ & $\$ 1400000$ \\
\hline $\begin{array}{l}\text { 2: } 282 \mathrm{~kL} / \text { day output MBR, one-to-many or } \\
\text { many-to-many }\end{array}$ & $(\$ 210000)$ & $\$ 1100000$ \\
\hline $\begin{array}{l}\text { 3: } 250 \mathrm{~kL} / \text { day Kraft to Boral 50\% MBR and 50\% } \\
\text { RO higher quality water than MBR only }\end{array}$ & $(\$ 1100000)$ & $(\$ 50000000000)$ \\
\hline $\begin{array}{l}\text { 4: } 250 \mathrm{~kL} / \text { day Kraft to Boral 100\% RO, one-to- } \\
\text { one (Kraft-to-Boral) }\end{array}$ & $(\$ 3800000)$ & $(\$ 2600000)$ \\
\hline $\begin{array}{l}\text { 5: } 250 \mathrm{~kL} / \text { day (50\% MBR recovered, 50\% } \\
\text { potable), one-to-one (Kraft-to-Boral) }\end{array}$ & $(\$ 1100000)$ & \\
\hline
\end{tabular}

Obtaining financial support for the project is a barrier, though not insurmountable the capital sums are modest and government and utilities are spending significant amounts on water saving initiatives as the system storages for the rain fed system in Melbourne sit below 30\% (a desalination plant with capacity of $150 \mathrm{GL} / \mathrm{a}$ is being built at a cost of approximately AUD 3 billion). The question of whether financial support is justified, relative to other activities which could be pursued to save water, depends to a large part on the other (including non-financial) barriers and opportunities which such a project contains. These barriers and opportunities in the Port Melbourne context are now discussed.

\subsection{Barriers and opportunities for water reuse synergies in Melbourne}

The challenges of rising water prices and trade waste prices act to make water recycling opportunities more cost-competitive with the price of water from the centralised mains water supply, however as Australia moves to implement an emissions trading scheme (Carbon Pollution Reduction Scheme), then the augmented energy requirements of a recycling scheme will impose an additional cost. A summary of drivers for water reuse synergies in Melbourne and their implications for this study are given in Table 3. 
Table 3: Summary of context

\begin{tabular}{|c|c|c|}
\hline Item & Description & Implications for study \\
\hline $\begin{array}{l}\text { Central Region } \\
\text { Sustainable Water } \\
\text { Strategy } \\
\text { and } \\
\text { Water supply-demand } \\
\text { strategy for Melbourne }\end{array}$ & $\begin{array}{l}\text { The Victorian Government has set } \\
\text { short-term water conservation } \\
\text { targets for the Central Region: } \\
\text { - } 25 \% \text { reduction (from } 1990 \text { s level) in } \\
\text { overall and residential per capita } \\
\text { drinking water use by } 2015 ; 30 \% \text { by } \\
20 ? 0\end{array}$ & $\begin{array}{l}\text { Contributions to reducing } \\
\text { potable water consumption and } \\
\text { consumption in the non- } \\
\text { residential sector will assist in } \\
\text { meeting targets. }\end{array}$ \\
\hline & $\begin{array}{l}2020 \\
\text { - at least } 1 \% \text { annual reduction in } \\
\text { current water consumption in the } \\
\text { non-residential sector }\end{array}$ & $\begin{array}{l}\text { The current recycled water } \\
\text { target for Melbourne is } 20 \% \text { by } \\
2010 \text {. }\end{array}$ \\
\hline Water price increases & $\begin{array}{l}\text { Due to water scarcity and also } \\
\text { commitment to desalination as a } \\
\text { response, water prices are rising } \\
\text { significantly over next } 5 \text { yrs }\end{array}$ & $\begin{array}{l}\text { Securing a local water supply } \\
\text { through recycling becomes } \\
\text { more cost-competitive }\end{array}$ \\
\hline Trade waste review & $\begin{array}{l}\text { Being conducted by Department of } \\
\text { Sustainability and Environment and } \\
\text { may lead to new charges for trade } \\
\text { waste, particularly relating to metals }\end{array}$ & $\begin{array}{l}\text { Potential of increased trade } \\
\text { waste charges provides further } \\
\text { incentive for recycling between } \\
\text { industries }\end{array}$ \\
\hline \multirow{2}{*}{$\begin{array}{l}\text { Carbon Pollution } \\
\text { Reduction Scheme } \\
\text { (proposed Australian } \\
\text { emissions trading) }\end{array}$} & \multirow[t]{2}{*}{$\begin{array}{l}\text { Carbon intensity of options will have } \\
\text { a future cost }\end{array}$} & $\begin{array}{l}\text { Favours water efficiency options } \\
\text { over recycling which is more } \\
\text { energy intensive }\end{array}$ \\
\hline & & $\begin{array}{l}\text { Promotes use of cleaner energy } \\
\text { sources including cogeneration }\end{array}$ \\
\hline Proximity to city & $\begin{array}{l}\text { Land use in Port Melbourne is } \\
\text { changing with less heavy industry } \\
\text { and more commercial / light industry }\end{array}$ & $\begin{array}{l}\text { Consider current and future } \\
\text { configuration of land uses in } \\
\text { study }\end{array}$ \\
\hline $\begin{array}{l}\text { Melbourne Water } \\
\text { Sewage Strategy } \\
2060\end{array}$ & $\begin{array}{l}\text { Role of centralised and decentralised } \\
\text { infrastructure for Melbourne being } \\
\text { re-examined }\end{array}$ & $\begin{array}{l}\text { Consider localised water } \\
\text { treatment facility in Port } \\
\text { Melbourne within wider network }\end{array}$ \\
\hline
\end{tabular}

The last item envisages a greater role for localised water treatment plants, given that these will need new governance models and institutional arrangements, implementing one of the discussed options discussed could provide a pilot case to resolving such issues.

As individual companies have their own views, stakeholder interviews were undertaken to assess their individual barriers and opportunities. These are explored further in the next section and contrasted with those presented by companies in the Kwinana Industrial Area, which was chosen for comparison as it has a history of successful implementation of water, energy and by-product synergies. 


\section{BARRIERS AND OPPORTUNITIES - COMPARISON BETWEEN PORT MELBOURNE AND KWINANA INDUSTRIAL AREA (KIA)}

Valuable lessons can be learned from regional synergy experiences in Kwinana. The diverse range of identified barriers and opportunities at KIA has contributed to the long lasting cooperation between companies, facilitated by the Kwinana Industries Council (KIC) which addresses a broad range of issues common to the industries in the area. KIA is recognised as a best practice example in implementation of regional synergies, characterised with its maturity, number of resource exchanges and the diverse blend of key processing and manufacturing industries [23].

Table 4 below presents the major barriers and opportunities for both industrial areas Kwinana and Port Melbourne. Although not all drivers, barriers, and trigger events listed in the table are discussed in detail, some specific examples from Kwinana are also provided below to illustrate each of the main categories. The listed barriers and opportunities for KIA refer to the whole range of regional synergies (by-product and utility) and these are defined as a result of the in depth study carried out at Curtin University of Technology, WA, since 2004 [33]. On the other hand the identified barriers and opportunities for Port Melbourne only emerged as a result from the scoping study discussed and are limited only to potential water synergies. As can be seen from the table, whilst some barriers and opportunities are similar (corporate social responsibility within companies), there are differing region-specific issues. 
Table 4 Barriers and Opportunities for Regional Synergies

\begin{tabular}{|c|c|c|c|}
\hline \multicolumn{2}{|c|}{ Kwinana Industrial Area } & \multicolumn{2}{|c|}{ Port Melbourne } \\
\hline Barriers & Opportunities & Barriers & Opportunities \\
\hline \multicolumn{4}{|l|}{ Economics } \\
\hline $\begin{array}{l}\text { - Relatively low price for utility } \\
\text { resources discourages } \\
\text { recycling } \\
\text { - Relatively low costs for waste } \\
\text { disposal }\end{array}$ & $\begin{array}{l}\text { - Increased revenue } \\
\text { - Secure availability and } \\
\text { access to vital process } \\
\text { resources }\end{array}$ & $\begin{array}{l}\text { Higher unit cost }(\$ / \mathrm{kL}) \text { for } \\
\text { recycled water than efficiency } \\
\text { or desalination due to limited } \\
\text { size of recycling plant }\end{array}$ & $\begin{array}{l}\text { Water price security - lock } \\
\text { in price for recycled supply } \\
\text { to insulate against further } \\
\text { rises in mains water } \\
\text { charges }\end{array}$ \\
\hline \multicolumn{4}{|l|}{ Information availability } \\
\hline $\begin{array}{l}\text { - Confidentiality and } \\
\text { commercial issues }\end{array}$ & $\begin{array}{l}\text { - Strong industry } \\
\text { organisation } \\
\text { - Local and regional studies } \\
\text { have been undertaken }\end{array}$ & $\begin{array}{l}\text { - Uncertainty around quality } \\
\text { tolerances for input water } \\
\text { required }\end{array}$ & $\begin{array}{l}\text { - Sharing information may } \\
\text { identify further synergies } \\
\text { (not water) }\end{array}$ \\
\hline \multicolumn{4}{|c|}{ Corporate social responsibility and business strategy } \\
\hline $\begin{array}{l}\text { - Core business focus } \\
\text { - Community engagement and } \\
\text { perception }\end{array}$ & $\begin{array}{l}\text { - Corporate sustainability } \\
\text { focus } \\
\text { - Community engagement } \\
\text { and perception }\end{array}$ & $\begin{array}{l}\text { - Cultural challenges within a } \\
\text { company }\end{array}$ & $\begin{array}{l}\text { - Corporate sustainability } \\
\text { focus }\end{array}$ \\
\hline \multicolumn{4}{|l|}{ Region specific issues } \\
\hline $\begin{array}{l}\text { - Distance between companies } \\
\text { inhibits synergies }\end{array}$ & $\begin{array}{l}\text { Major new project } \\
\text { developments provide } \\
\text { opportunities for new } \\
\text { synergies }\end{array}$ & $\begin{array}{l}\text { - Changing industry presence in } \\
\text { area (less heavy industry) } \\
\text { - Some companies located } \\
1.5 \mathrm{~km} \text { from main cluster of } \\
\text { companies } \\
\text { - Limited land availability }\end{array}$ & $\begin{array}{l}\text { - Water scarcity encouraging } \\
\text { a range of water saving } \\
\text { options to be explored } \\
\text { - Expansion development }\end{array}$ \\
\hline \multicolumn{4}{|l|}{ Regulation } \\
\hline $\begin{array}{l}\text { - Existing environmental } \\
\text { regulations }\end{array}$ & $\begin{array}{l}\text { New pollutant targeted } \\
\text { regulations } \\
\text { (e.g. carbon tax and } \\
\text { mandatory energy audits) }\end{array}$ & $\begin{array}{l}\text { Third parties (other than } \\
\text { government utility) cannot sell } \\
\text { recycled water to companies } \\
\text { in Victoria }\end{array}$ & $\begin{array}{l}\text { Trade waste review could } \\
\text { raise costs for discharge } \\
\text { and encourage recycling }\end{array}$ \\
\hline \multicolumn{4}{|l|}{ Technical issues } \\
\hline $\begin{array}{l}\text { - Availability of (reliable) } \\
\text { recovery technologies }\end{array}$ & $\begin{array}{l}\text { - Major brownfield } \\
\text { development within } \\
\text { company }\end{array}$ & $\begin{array}{l}\text { Water quality requirements } \\
\text { for receiving companies } \\
\text { - Perceived water quality and } \\
\text { health and safety risks of } \\
\text { recycled water }\end{array}$ & $\begin{array}{l}\text { - Opportunity to link with } \\
\text { cogeneration on site } \\
\text { - Water reuse synergies } \\
\text { versus on-site efficiency? }\end{array}$ \\
\hline
\end{tabular}

\subsection{Economics}

Operational costs and revenue as synergy opportunity: The Port Melbourne water reuse synergy would only be viable with financial subsidy due to the higher unit costs than water efficiency and desalination options. In Kwinana, securing access to water is a greater driver in addition to synergy projects making good business sense, through a combination of lower input costs, lower operational costs and/or increased revenues. One of the recently identified synergies in Kwinana features a mineral processing plant that produces an effluent stream containing a small fraction of hydrocarbons. The plant's water treatment is not designed to treat hydrocarbons so this effluent is currently disposed as waste at very high costs. The BP refinery wastewater treatment plant is especially designed to target hydrocarbons and could feasibly treat the effluent. The two companies are working on the operational arrangements (e.g. contracts) at present [34]. 
Resource scarcity as an economic opportunity: A number of utility synergies have come to fruition because of concerns for continued access to a vital resource for running the business. The development of the Kwinana Water Reclamation Plant (KWRP) in 2004 was triggered to accommodate the establishment of HIsmelt (direct smelting) which was unable to secure another source of large volume process water [35]. In contrast in Port Melbourne, the concern was not over access to the water resource, but rather to water price security, meaning that by linking with the water reuse synergy, a fixed price may be negotiated thus avoiding planned future price rises in the mains supply.

\subsection{Information availability}

Local and regional studies as synergy opportunity: While some synergies were already happening it took an external study to review and document regional resource flows and synergy opportunities to create broader industry interest and commitment for industrial symbiosis. In Kwinana, the regional economic impact study was coordinated by the Kwinana Industries Council and financially supported by the Commonwealth and state government. It revealed the exponential growth in the industry integration in the area over the 1990s, and suggested many more exchanges would in principle be possible. Similarly this study undertaken in Port Melbourne has identified further potential for co-generation in the area and implementation of a water reuse initiative could be used as a vehicle for closer collaboration amongst companies to realised synergies with energy and other resources.

\subsection{Corporate social responsibility and business strategy}

Community engagement and corporate sustainability as synergy opportunity: Industrial ecology opportunities can be driven by corporate social responsibility [36]. Kwinana is increasingly subject to urban encroachment and resulting higher community expectations, with regard to environmental and safety performance, and overall amenity. Kwinana is located on the shore of the Cockburn Sound, a sensitive marine environment and recreational area for local residents. The opportunity to transfer the discharge of treated process wastewater from the coastal area into the deep ocean outlet as part of the KWRP project was therefore an important consideration for local companies. In Port Melbourne, high-rise urban development is 
occurring at Docklands located adjacent to Port Melbourne and overlooks the company sites. Several Port Melbourne companies are interested in pursuing a 'green icon' project for the region and this could act as a trigger for strengthening relationships with the local communities and amongst neighbouring companies. However, if recycled water were to be the selected project, it would need to be linked with a clean energy source due to the increased energy intensity of the process compared with mains water.

Core business focus as synergy barrier: The focus of site personnel is on core business activities resulting in potential missed synergy opportunities unless there is an overwhelming commercial benefit. This has been discussed by Deutz and Gibbs [8]. This is also recognised by various site personnel who see one of the main aims of the regional synergies research is to identify and progress synergy opportunities, which are unrelated to core business. In Port Melbourne this is less of a concern as the utility would be the owner and operator of the plant.

\subsection{Region-specific issues}

Major capital projects as synergy opportunity: This refers to the opportunity to implement synergies when major capital projects are being undertaken. This can include new operations or significant capacity expansion projects in existing operations. In Port Melbourne there are no major heavy industrial customers coming to the region, rather there are more light industrial and commercial companies moving to the area. This contrasts Kwinana, where two new industrial facilities have been built and commissioned in 2004 (Kwinana Water Reclamation Plant and HIsmelt direct reduction iron making plant). The HIsmelt plant will be able to source a number of inputs locally in the Kwinana area, such as lime, lime kiln dust and treated wastewater and provide outputs with potential for reuse in the KIA, such as slag and gypsum. HIsmelt triggered the undertaking of the Kwinana Water Reclamation Plant (KWRP) as the groundwater allocation for the area had already been licensed to the existing industries and there was limited availability of catchment (scheme) water in Perth Metropolitan area.

Distance between companies as synergy barrier: The distance between companies has been identified as a synergy barrier [35]. For the recovery and reuse of process energy and water the distance between involved operations does make it more complicated than just transferring a by-product across a boundary fence to a 
neighbouring operation. Transporting water over longer distances is generally limited by the cost of piping and pumping as well as the layout of the established industrial operations. In Port Melbourne, this may favour a direct exchange between neighbouring companies rather than a centralised treatment plant which would need to cross many major roads.

\subsection{Regulation}

Environmental regulations as synergy barrier: Kwinana companies are experiencing obstacles in obtaining governmental approvals for use of alternative fuels and materials Although some by-product synergies appear techno-economical feasible and have a positive sustainability impact (e.g. alternative fuels in cement kilns, and use of bauxite residue for soil conditioning), their practical implementation have been halted by uncertainties in the legislative framework, in particular with regard to the final responsibility for approved reuse options, and community concern. Additionally, if a by-product is classified as a controlled waste (for example fly ash), strict transportation procedures and requirements apply. In Melbourne (and hence Port Melbourne) there is currently not provision for private operators to sell water (nor recycled water). This presents a barrier to an industry owned and operated plant, however, it is not the core business of the companies involved and their interest in establishing a plant as a revenue generating centre is limited - the business proposition is not favourable enough. Hence the most likely scenario would be for the government owned utility (South East Water) to own and operate the plant. The situation for private players entering as water retailers in Melbourne may change in future, however the Port Melbourne case study is unlikely to motivate such a change in legislation. By way of comparison, the state of New South Wales has recently enacted the Water Industry Competition Act (2006) allowing third parties to become licensed water retailers and local councils in Sydney to sell water. The success of this legislation as it becomes tested would provide useful input to any Melbournebased proposals seeking to adopt a similar approach.

\subsection{Technical issues}

Technical obsolescence of existing process equipment as synergy opportunity: The Kwinana Cogeneration Plant is located on land of the BP oil refinery, and produces all process steam for the refinery, and generates electricity for BP as well as the grid. 
The cogeneration plant is fired with excess refinery gas from the oil refinery supplemented with natural gas. The cogeneration plant built in 1996, substituted both BP steam boilers that were in need of replacement at the time. This synergy is estimated to have saved the refinery in approximately 15 million AUD in capital expenditure while ensuring a cost competitive reliable source of steam and electricity for their refinery. In addition BP provides process water to the cogeneration plant and accepts their wastewater stream. A willingness to assess developing co-generation opportunities was identified in Port Melbourne, but is only currently being explored in detail.

Role of regional synergies versus on-site efficiency: A key consideration for water reuse synergy projects is how recycling waste water for use at an adjacent site affects the pursuit of future water efficiency opportunities on site (which are very cost effective). Once a recycled water plant had started operation, reductions in water discharges to feed the plant (and increases in pollutant loads) would affect the viability of the recycled plant. Whilst an important consideration for water reuse synergies in Port Melbourne, this is less of a concern for other material exchanges in Kwiniana where by-products from some processes currently have no other uses and any reuse opportunity is beneficial. This highlights the importance of the cost effectiveness framework for contrasting the two.

\section{PLAN FOR FUTURE REGIONAL SYNERGY DEVELOPMENT}

This paper has provided an overview of the Port Melbourne scoping study of water reuse opportunities. By contrasting barriers and opportunities for regional synergy development between Kwinana and Port Melbourne, insights can be gained into the strategy which can lead to successful implementation. This has been proposed in the following stages:

- Establish Port Melbourne Industrial Ecology working group

- Further review of costs, technologies and funding with utility and stakeholders

- Option and technology selection for detailed assessment

- Broader stakeholder consultation

- Pilot testing of water qualities

- In-principle commitment (MOU) from companies

- Regulatory approvals

- Detailed design 
- Liaise with companies regarding contracts

- Acquire land and capital for development

- Facility Construction

- Company interconnections and pipe work

- Commissioning

- Operation

- Monitoring and evaluation.

\section{CONCLUSIONS AND FUTURE RECOMMENDATIONS}

The results of this study demonstrated that there are at least five possible synergy reuse options that are technically feasible, however further pilot testing of input water quality would be required for receiving plants. All options require a financial subsidy to be viable and there is the potential to secure such assistance from the government and utilities. The use of a cost effectiveness framework to evaluate options shows that the $\$ / \mathrm{kL}$ increases with smaller plant size and also with the use of Reverse Osmosis technology (in addition to MBR technology). The pilot trials of whether the output quality from MBR options is sufficient for use directly as a process input would shape the final choice. The cost effectiveness metric also allows a broader comparison with other options open to the utility to realise water savings. It shows reuse at Port Melbourne to be more costly than water efficiency and large scale desalination. In addition to describing options, the authors have emphasised the process by which the options are developed. Successful implementation of regional synergies from Kwinana has shown the central role of establishing trust amongst participating stakeholders and for this reason the participating companies in Port Melbourne agreed to meet independently following the facilitated scoping study project as an Industrial Ecology Group and have begun to explore further opportunities for synergies beyond water. Work is currently focussing on the energy implications of water reuse synergies and exploration of co-generation opportunities. The range of barriers and opportunities identified and compared between Kwinana and Port Melbourne will be of interest to others seeking to implement reuse synergies and underlines the need to asses local context as several barriers differ markedly.

Further research is required within the industrial ecology community to ascertain when and at what scale reuse synergies should be pursued and when and at what 
scale efficiency should be prioritised, and how this varies for water, energy and other materials.

Given the benefits of contrasting Kwinana and Port Melbourne experiences, further efforts could usefully be undertaken to establish a network of regional industry councils (e.g. Gladstone Area Industry Network, Kwinana Industries Council, Geelong Manufacturing Council, Port Melbourne Industrial Ecology Group) for sharing lessons and implementation strategies.

\section{ACKNOWLEDGEMENTS}

The authors wish to thank the Victorian Smart Water Fund for funding this project; Mike Mcrae-Williams (Hatlar Consulting) for developing equipment costs; Dick van Beers (Centre for Sustainable Resource Processing, Curtin University of Technology) for valuable research contributions to earlier stages of this project; company participants for their time and willing involvement, namely, Troy White (Kraft), Greg Crawford (Boral) Paramjeet Thaker(Symex), Simon Renton (GM Holden), Kevin Greaves (GM Holden), Adam Moran (Boeing), Chris Wanless (Crema), Robert Mrzljak (Independent Cement), Peter Garner (Herald Weekly Times); and South East Water personnel Terry Anderson, Matt Walker and Vanessa Lenihan for endorsing this case study.

\section{REFERENCES}

[1] Chertow M. Industrial Symbiosis: Literature and Taxonomy. Annual review of energy and the environment. 2000;25(1):313-37.

[2] Chertow M. " Uncovering" Industrial Symbiosis. Journal of Industrial Ecology. 2007;11(1):11.

[3] Chertow MR, Lombardi DR. Quantifying Economic and Environmental Benefits of Co-Located Firms. Environmental Science \& Technology. 2005;39(17):6535-41.

[4] Geng Y, Zhu Q, Doberstein B, Fujita T. Implementing China's circular economy concept at the regional level: A review of progress in Dalian, China. Waste Management. 2009;29(2):996-1002.

[5] Geng Y, Cote R. Applying industrial ecology in rapidly industrializing Asian countries. International Journal of Sustainable Development \& World Ecology. 2004;11(1):69 - 85.

[6] van Schaik A, Reuter MA, van Stokkom H, Jonk J, Witter V. Management of the Web of Water and Web of Materials. Minerals Engineering.23(3):157-74.

[7] Shi H, Chertow M, Song Y. Developing country experience with eco-industrial parks: a case study of the Tianjin Economic-Technological Development Area in China. Journal of Cleaner Production.18(3):191-9.

[8] Deutz P, Gibbs D. Industrial ecology and regional development: eco-industrial development as cluster policy. Regional Studies: The Journal of the Regional Studies Association. 2008;42(10):1313-28. 
[9] Bossilkov A, van Berkel R, Corder G. Regional Synergies for Sustainable Resource Processing: A status report. Perth, Australia: Centre for Sustainable Resource Processing; 2005.

[10] Lowe E. Eco-industrial park handbook for Asian developing countries. Report to Asian Development Bank; 2001.

[11] Cohen-Rosenthal E. Making sense out of industrial ecology: a framework for analysis and action. Journal of Cleaner Production.12(8-10):1111-23.

[12] Lowe EA. Creating by-product resource exchanges: Strategies for eco-industrial parks. Journal of Cleaner Production. 1997;5(1-2):57-65.

[13] White S, Fane S, Giurco D, Turner A. Putting the economics in its place:

decision making in an uncertain environment. In: Zografos $C$, Howarth R, editors.

Deliberative Ecological Economics. New Dehli, India: Oxford University Press; 2006. p. 80-106.

[14] White S, Fane S. Designing cost effective water demand management programs in Australia. Water Science \& Technology. 2002;46(6):225-32.

[15] Turner A, Willetts J, Fane S, Giurco D, Kazaglis A. Guide to Demand Management, prepared for Water Services Association of Australia. Institute for Sustainable Futures, UTS, Sydney. 2008.

[16] Mitchell C, Fane S, Willetts J, Plant R, Kazaglis A. Costing for Sustainable Outcomes in Urban Water Systems: A Guidebook. CRC for water quality and treatment research report. 2007;35.

[17] White S, Campbell D, Giurco D, Snelling C, Kazaglis A, Fane S. Review of the Metropolitan Water Plan: Final Report. Sydney: Institute for Sustainable Futures, UTS and ACIL Tasman; 2006.

[18] van Beers D, Bossilkov A, van Berkel R. A regional approach using synergy to advance sustainable water use: a case study using Kwinana (Western Australia). Australasian Journal of Environmental Management. 2008;15(September):149-58. [19] Geng Y, Yi J. Integrated water resource management at the industrial park level: a case of the Tianjin Economic Development Area. International Journal of Sustainable Development and World Ecology. 2006;13(1):37-51.

[20] Our Water Our Future. Central Region Sustainable Water Strategy. Melbourne: Victorian Government; 2006.

[21] Turner A, Willets J, Fane S, Giurco D, Kazaglis A, White S. Guide to demand management. Sydney: Water Services Association of Australia; 2008.

[22] van Beers $D$, Bossilkov $A$, van Berkel $R$. A regional synergy approach to advance sustainable water use: a case study using Kwinana (Western Australia). Australasian Journal of Environmental Management 2008;15(3):149-58.

[23] Kazaglis A, Giurco D, Van Beers D, Bossilkov A, Reuter M, Fagan J, et al. Industrial ecology opportunities in Melbourne: literature review. Sydney: Institute for Sustainable Futures, UTS; [prepared for Smart Water Fund, Melbourne]; 2007.

[24] Bossilkov A. Regional Eco-Efficiency Opportunity Assessment Methodology Trial Application for Kwinana and Gladstone. Centre for Sustainable Resource Processing, Perth, WA. 2006.

[25] Heeres RR, Vermeulen WJV, de Walle FB. Eco-industrial park initiatives in the USA and the Netherlands: first lessons. Journal of Cleaner Production. 2004;12(810):985-95.

[26] Fane S, Ashbolt N, White S. Decentralised urban water reuse: The implications of system scale for cost and pathogen risk. Water Science \& Technology. 2002;46(6):281-8.

[27] EPA Victoria. Use of reclaimed water. Guidelines for environmental management. Melbourne: Environmental Protection Authority Victoria; 2003.

[28] Fane SA, Robinson J, White S. The use of levelised cost in comparing supply and demand side options for water supply and wastewater treatment. Water supply. 2003;3(3):185-92. 
[29] Essential Services Commission. Metropolitan Melbourne Water Price Review 2009 - Draft Decision, Vol 1.: April; 2009.

[30] Needham S. The potential for renewable energy to provide baseload power in Australia: Research Paper no 9 2008-09. 2008.

[31] Marsden Jacob Associates. Securing Australia's urban water suppliers: opportunities and impediments.: Department of Prime Minister and Cabinet, Australian Government; 2006.

[32] Independent Pricing and Regulatory Tribunal (New South Wales). WICA Fact Sheet: Overview of licensing regime under the Water Industry Competition Act 2006. 2008.

[33] van Beers D, Corder GD, Bossilkov A, van Berkel R. Regional synergies in the Australian minerals industry: Case-studies and enabling tools. Minerals Engineering. 2007;20(9):830-41.

[34] van Beers D. Capturing Regional Syergies in the Kwinana Industrial Area: 2008 Status report. Centre for Sustainable Resource Processing, Perth, WA. 2008.

[35] van Beers D, Corder G, Bossilkov A, van Berkel R. Industrial symbiosis in the Australian minerals industry. Journal of Industrial Ecology. 2007;11(1):55-72.

[36] Korhonen J. Industrial ecology in the strategic sustainable development model: strategic applications of industrial ecology. Journal of Cleaner Production.12(810):809-23. 
Vitae

Damien Giurco

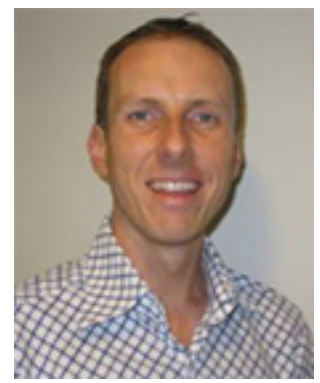

Dr Damien Giurco is a Research Director at the Institute for Sustainable Futures, University of Technology, Sydney with research interests in industrial ecology, resource futures in the water, energy and minerals sectors. He is currently leading the Mineral Futures program of work exploring what sustainable patterns of production and consumption mean for commodity, technology and regional futures. Damien holds a Bachelor of Chemical Engineering (Hons) and Bachelor Science both from the University of Melbourne and a PhD from the University of Sydney.

\begin{abstract}
Albena Bossilkov
Albena Bossilkov is a Senior Research Fellow at the Centre of Excellence in Cleaner Production at Curtin University focusing on cleaner production, eco-efficiency and industrial ecology. This has involved development of a regional eco-efficiency opportunity assessment methodology and toolkit which have been applied to identify waste exchange opportunities for by-products, water and energy in various industrial areas in Australia and internationally. Albena holds a Bachelor of Chemical Engineering (Hons) and a postgraduate degree in Cleaner Production and is currently studying towards a Doctoral degree. In addition she has almost 10 years experience in Printed Circuits manufacturing at support and management positions (quality assurance and environmental management).
\end{abstract}

\title{
James Patterson
}

James Patterson's contribution to this research was working as a Research Consultant at the Institute for Sustainable Futures, University of Technology, Sydney. James' research focuses on Integrated Resources Planning (IRP) for urban water, community processes and participation in decision-making, sustainability at the local community and local government scale. He holds a Bachelor of Engineering (Civil) and Bachelor of Engineering (Environmental) from the University of New South Wales where he received first class honours and the University Medal for academic achievement.

\footnotetext{
Alex Kazaglis

Alex Kazaglis' contribution to this research was working as a Senior Research Consultant at the Institute for Sustainable Futures, University of Technology, Sydney. His research experience is focussed on sustainability and urban water management. Alex holds a Bachelor of Engineering (Hons I) and Bachelor of Science from the University of New South Wales and a Master of Science in Environment \& Development from the London School of Economics. Alex is currently Senior Analyst, Energy Use in Buildings \& Industry at the UK Committee on Climate Change Secretariat.
} 